\title{
Hepatitis $C$ virus genotyping based on Core and NS5B regions in Cameroonian patients
}

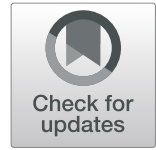

\author{
Paul Alain Tagnouokam-Ngoupo, Marie Nicole Ngoufack, Sebastien Kenmoe, Simon Frédéric Lissock, \\ Marie Amougou-Atsama, Robert Banai, Laure Ngono and Richard Njouom ${ }^{*}$
}

\begin{abstract}
Background: Current HCV treatments are genotype specific although potential pan-genotype treatments have recently been described. Therefore, genotyping is an essential tool for the therapeutic management of HCV infection and a variety of technologies have been developed for HCV genotypes determination. Sequences analysis of HCV sub-genomic regions is considered as gold standard and is widely used for HCV genotyping. Here, we compared HCV genotyping using core and NS5B regions in routine practice in HCV-positive Cameroonian patients.

Methods: All plasma samples received at Centre Pasteur of Cameroon (CPC) in 2016 for HCV genotyping were included. Viral loads were determined using the Abbott Real Time assay. Further, genotyping was based on the amplification and sequencing of core and NS5B regions following by phylogenetic analysis of corresponding sequences.
\end{abstract}

Results: A total of 369 samples were received during the study period with high viral load values (median: 930,952 IU/ml; IQR: 281,833-2,861,179). Positive amplification was obtained in at least one genomic region (core or NS5B) for all the samples with similar amplification rate in the two genomic regions $(p=0.34)$. Phylogenetic analysis showed that among the 369 samples, 146 (39.6\%) were classified as genotype 4, 132 (35.8\%) as genotype 1, 89 (24.1\%) as genotype 2 , in both core and NS5B regions. Interestingly, for two samples (0.54\%) discordant genotypes were obtained in both regions with the core region classified as genotype 4 while the NS5B was identified as genotype 1 indicating the presence of putative HCV recombinant virus or multiple infections in these samples. Discrimination of HCV subtypes was most likely possible with NS5B compared to core region.

Conclusions: We found high amplification rates of HCV in both core and NS5B regions, and a good concordance was obtained at genotype level using both regions except for two samples where putative 1-4 recombinants/ multiple infections were detected. Therefore, HCV genotyping based on at least two genomic regions could help to identify putative recombinants and improve therapeutic management of HCV infection.

Keywords: HCV, Genotyping, Core, NS5B, Genotypes, Subtypes, Cameroon

\section{Background}

Hepatitis $\mathrm{C}$ virus (HCV) is classified into seven genotypes, 67 confirmed subtypes and 20 provisionally assigned subtypes $[1,2]$. Genotypes $1-3$ are common worldwide, while genotypes 4 and 5 are mostly found in lower-income countries. Genotypes 1, 2 and 4 have been shown to co-circulate in Cameroon [3, 4]. There is no vaccine against HCV, but many HCV treatment options and cure rates have greatly increased in the last decade with the development of direct-

\footnotetext{
* Correspondence: njouom@pasteur-yaounde.org

Virology Department, Centre Pasteur of Cameroon, 451 rue 2005 Yaounde 2, Po Box 1274, Yaounde, Cameroon
}

acting antivirals (DAA) [5]. Most often these DAA therapies are genotype specific although some pan-genotype $\mathrm{HCV}$ treatments have recently been described and approved by stringent regulatory authorities [6-8]. Actually, these pangenotypic drugs are mostly used in developing countries and in clinical trials because of their high costs [9]. Despite the opportunities to access low-price generic medicines are increasing, treatment of $\mathrm{HCV}$ infection in developing countries relies on genotype specific DAAs ("https://www.who.int/ hepatitis/news-events/hep-c-access-report-2018-key-messages/en/"). Therefore, genotyping is an essential tool for the therapeutic management of $\mathrm{HCV}$ infection and a variety of 
technologies have been developed for HCV genotypes determination.

Restriction fragment length polymorphism (RFLP) analysis has been developed for some $\mathrm{HCV}$ genomic regions: the $5^{\prime}$ non-coding and the contiguous core regions. The choice of these genomic sequences was based on their relative nucleotide homology among different genotypes and the presence of polymorphic sites [10]. RFLP is performed using endonucleases that will break down the DNA amplicons at specific sites, different $\mathrm{HCV}$ genotypes and subtypes will therefore be illustrated by RFLP digestion patterns on agarose gel. However, a mutation occurring in one of the polymorphic sites recognized by the restriction endonuclease could be could be limiting for HCV genotyping and subtyping [10].

Other methods are based on the $5^{\prime}$ untranslated (5'UTR) region because of high conservation within genotypes but considerable variability between subtypes [11]. One of these methods is the line probe assay (LiPA), which is a reverse-hybridization assay based on variations found in $5^{\prime}$-UTR regions of the different hepatitis HCV genotypes and subtypes. The commercial test Versant HCV genotype assay developed by Siemens Laboratories is one of the most widely used LiPA methods for HCV genotyping. However, although LiPA is considered to be a good method for HCV genotyping, it is less suitable for HCV subtype's determination [12].

Today, amplification of HCV sub-genomic regions (core, E1 and NS5 regions), followed by sequences analysis is considered as gold standard and is widely used for HCV genotyping $[13,14]$. This method allows accurate identification of the subtype and is used for epidemiological studies of circulating virus strains. NS5B is the most common target region, however, some studies have shown a higher amplification rate of Core region compared to NS5B [15]. In addition, recombinant HCV viruses, with mosaic genome derived from two different genotypes have recently been described in Cameroon and abroad with discordant genotypes in both core and NS5B regions [16-20]. These intergenotypic recombinants involved genotypes 1 and 2, 1 and 4, and 2 and 5 . This recombination could be problematic for therapeutic management particularly if the DAA anti-viral treatment responses vary among genotypes and therefore, pointout the limitation of $\mathrm{HCV}$ genotyping based only on one genomic region [18, 21, 22].

In the present study, we compared $\mathrm{HCV}$ genotyping using core and NS5B regions in routine practice in HCV-positive Cameroonian patients in order to highlight potential impact on their therapeutic management. HCV Viral load was performed on all samples followed by direct sequencing of core and NS5B regions. Phylogenetic analyses using generated HCV sequences of both regions allowed the identification of genotypes as well as subtypes.

\section{Methods}

\section{Study population and HCV viral load}

The Centre Pasteur of Cameroon (CPC) is the reference laboratory for HIV and Hepatitis in Cameroon. As part of this role, patients are routinely referred to CPC for viral load and genotyping. Data reported here were collected in the framework of these routine activities and no additional parameter was assessed.

From January to December 2016, all samples received at $\mathrm{CPC}$ for $\mathrm{HCV}$ genotyping and viral load were included. Demographic data were recorded for all patients. The HCV viral loads were determined using the Abbott RealTime HCV assay and the Abbott m2000 platforms (Abbott molecular, Wiesbaden-Germany) according to the manufacturer's instructions. Briefly, $0.5 \mathrm{~mL}$ plasma sample (from EDTA tubes) was used for RNA extraction on the Abbott m2000sp followed by amplification using the m2000rt. The detection limit was $12 \mathrm{IU} / \mathrm{mL}$.

\section{Amplification and sequencing of Core and NSB regions}

For HCV genotyping, total RNA was extracted from $140 \mu \mathrm{L}$ of plasma using QIAamp ${ }^{\circ}$ Viral RNA Mini Kit (Qiagen, Courtaboeuf, France), according to the manufacturer's instructions, following by amplification of Core and NSB regions using nested polymerase chain reaction (nested-RT PCR).

For Core region, a fragment (400 nt) was amplified using primer pairs previously described by Lole et al. [23] with slight modifications on Core OS, Core IS and Core IAS (Table 1) reported by Njouom et al. [24]. The

Table 1 Primers used for amplification of Core and NS5B regions

\begin{tabular}{|c|c|c|}
\hline Genomic regions & Primers & Sequences (5'------3') \\
\hline \multirow[t]{4}{*}{ Core } & Core OS (outer $\mathrm{f}$ ) & ACTGCCTGATAGGGTGCTTGCGAG \\
\hline & Core OAS (outer r) & ATGTACCCCATGAGGTCGGC \\
\hline & Core IS (inner f) & AGGTCTCGTAGACCGTGCATCATG \\
\hline & Core IAS (inner r) & CAYGTRAGGGTATCGATGAC \\
\hline \multirow[t]{3}{*}{ NS5B } & SO755 (outer and inner f) & TATGAYACCCGCTGYTTTGACTC \\
\hline & ASO1121 (outer r) & GCNGARTAYCTVGTCATAGCCTC \\
\hline & ENO2BIS (inner r) & GCTAGTCATAGCCTCCTG \\
\hline
\end{tabular}


mixture of $10 \mu \mathrm{L}$ RNA and $2 \mu \mathrm{L}(150 \mathrm{ng} / \mu \mathrm{L})$ of random hexamer (NNNNNN) was used in the denaturation step at $70^{\circ} \mathrm{C}$ for $10 \mathrm{~min}$ following by the generation of cDNA at $42^{\circ} \mathrm{C}$ for $90 \mathrm{~min}$ using $8 \mathrm{U}$ of AMV Reverse Transcriptase (Promega Corporation, USA) and $200 \mu \mathrm{M}$ dNTPs. PCR step was then performed in a final volume of $50 \mu \mathrm{L}$ containing $1.5 \mathrm{U}$ of Taq polymerase (Life Technologies Corporation, USA), $0.2 \mu \mathrm{M}$ of each primer, 1.5 $\mathrm{mM} \mathrm{MgCl} 2,200 \mu \mathrm{M} d \mathrm{dTPs}$ and $5 \mu \mathrm{L}$ of cDNA. A Perkin Elmer Gene Amp PCR System 9700 was used with the following cycling conditions: $94^{\circ} \mathrm{C}$ for $3 \mathrm{~min}$, followed by two cycles of $95^{\circ} \mathrm{C}$ for $30 \mathrm{~s}, 60^{\circ} \mathrm{C}$ for $30 \mathrm{~s}$ and $72{ }^{\circ} \mathrm{C}$ for $30 \mathrm{~s}$ followed immediately by the two same cycles with an auto-decrement temperature of $1{ }^{\circ} \mathrm{C}$ until $51^{\circ} \mathrm{C}$, and then 20 cycles of $95^{\circ} \mathrm{C}$ for $30 \mathrm{~s}, 50^{\circ} \mathrm{C}$ for $30 \mathrm{~s}, 50^{\circ} \mathrm{C}$ for $30 \mathrm{~s}$ and final extension at $72{ }^{\circ} \mathrm{C}$ for $7 \mathrm{~min}$. Nested PCR step was further performed in the same conditions as the first round PCR.

For NS5B region, a fragment (382 nt) was amplified by RT-PCR "touch Down" followed by semi-nested PCR using the same primers as previously reported by Laperche et al. [25] and Njouom et al. [24]. RT-PCR was performed using SuperScript $^{\text {tix }}$ III One-Step RT-PCR System with Platinum ${ }^{\circ}$ Taq (Life Technologies Corporation, USA) in a final volume of $50 \mu \mathrm{L}$ containing $0.2 \mu \mathrm{M}$ of each primer, $2.3 \mathrm{mM} \mathrm{MgSO} 4$, $200 \mu \mathrm{M}$ dNTPs and $10 \mu \mathrm{L}$ of RNA extract. A Perkin Elmer Gene Amp PCR System 9700 was used with the following cycling conditions: $50^{\circ} \mathrm{C}$ for $30 \mathrm{~min}, 95^{\circ} \mathrm{C}$ for $2 \mathrm{~min}$, followed by five cycles of $93^{\circ} \mathrm{C}$ for $30 \mathrm{~s}, 60^{\circ} \mathrm{C}$ for $45 \mathrm{~s}$, and $72{ }^{\circ} \mathrm{C}$ for $1 \mathrm{~min}$ ), followed by 35 cycles of $93^{\circ} \mathrm{C}$ for $30 \mathrm{~s}, 60^{\circ} \mathrm{C}$ for $45 \mathrm{~s}$, and $72^{\circ} \mathrm{C}$ for $1 \mathrm{~min}$ with an auto-decrement temperature of $0.3{ }^{\circ} \mathrm{C}$ for annealing at each cycle. The final extension was at $72^{\circ} \mathrm{C}$ for $10 \mathrm{~min}$. In the second round PCR, $2 \mu \mathrm{L}$ of RT-PCR products were used in a final volume of $50 \mu \mathrm{L}$ containing $1.25 \mathrm{U}$ of Taq polymerase, $0.2 \mu \mathrm{M}$ of each primer, and $1.5 \mathrm{mM} \mathrm{MgCl}_{2}$. The cycling conditions consisted of $95^{\circ} \mathrm{C}$ for $5 \mathrm{~min}$ followed by 35 cycles of $95^{\circ} \mathrm{C}$ for $30 \mathrm{~s}$, $55^{\circ} \mathrm{C}$ for $30 \mathrm{~s}, 72^{\circ} \mathrm{C}$ for $30 \mathrm{~s}$ and a final extension step of $72^{\circ} \mathrm{C}$ for $10 \mathrm{~min}$.

All nested-PCR products of both core and NS5B regions were further sequenced by Sanger method using GenomeLab DTCS-Quick Start Kit (Beckman Coulter, Paris, France) according to manufacturer's instructions.

\section{Determination of HCV genotypes and subtypes}

Nucleotides sequences obtained in both regions were aligned by ClustalW with reference sequences representing HCV genotypes and subtypes retrieved from Genbank (http://www. ncbi.nlm.nih.gov/genbank/). Phylogenetic trees were further constructed in MEGA 6.06 software by the neighbor-joining method with the Kimura two-parameter method for computing evolutionary distances [26]. Robustness of the tree topologies was estimated by bootstrap analysis with 1000 pseudo-replicate data sets, and only bootstrap values $>70$ were considered significant.

\section{Statistical analysis}

Statistical analysis was performed with the $\mathrm{R}$ version 3.4.1 software. $P$-value $\leq 0.05$ determined with Fisher's Exact Test or Pearson chi-square test was considered significant.

\section{Results}

\section{Samples and viral load}

A total of 369 samples were received during the study period with $212(57.5 \%)$ from females. The median age of the patients was 62 years [Interquartile range (IQR): 56-69 years]. Globally, high viral load values were obtained with a median viral load of 930,952 IU/ml (IQR: 281,833-2,861,179) or $6 \mathrm{LogIU} / \mathrm{ml}$ (IQR: 5.4-6.5). No information on treatment was available for all the patients.

\section{Amplification rate of Core and NS5B regions}

A positive amplification was obtained in at least one genomic region (core or NS5B) for all the samples with similar amplification rate in the two genomic regions $(p=0.34)$. Three hundred and forty six $(93.8 \%)$ samples were positive in the core region while 338 (91.6\%) were positive in the NS5B region. Three hundred and fifteen samples were positive in both regions $(85.4 \%), 31(8.4 \%)$ samples positive in core region only and $23(6.2 \%)$ samples positive in the NS5B region only (Table 2).

Amplification rates varied with viral load in both core and NS5B regions (Table 3), but the difference did not reach statistical significance $(p=0.07)$ indicating that there is a high probability to have a positive result for $\mathrm{HCV}$ genotyping in Cameroonian patient using the primers and methods described here.

\section{Performance of HCV genotyping using Core and NS5B sequence analysis}

Phylogenetic analysis showed that among the 369 samples, $129(39.6 \%)$ were classified as genotype 4, 132 (35.8\%) as genotype 1, and $89(24.1 \%)$ as genotype 2, in both core and/or NS5B regions. Among all, genotypes were assigned in both core and NS5B for 129 samples for genotype 4, 107 samples for genotypes 1 and 77 samples for genotypes 2 (Table 4). For 10 other samples for genotype 1, 8 for genotype 2 and 5 for genotype 4, classification was based on NS5B only, while for 15 samples

Table 2 Amplification rate of Core and NS5B regions

\begin{tabular}{lllll}
\hline & & \multicolumn{3}{l}{ Core region } \\
\cline { 3 - 5 } & & Positive & Negative & Total \\
\hline NS5B region & Positive & 315 & 23 & $338(91.6 \%)$ \\
& Negative & 31 & 0 & $31(8.4 \%)$ \\
& Total & $346(93.8 \%)$ & $23(6.2 \%)$ & $369(100 \%)$ \\
\hline
\end{tabular}


Table 3 The amplification rate of Core and NS5B regions according to HCV viral loads

\begin{tabular}{llll}
\hline & & \multicolumn{2}{l}{ Number of positive samples } \\
\cline { 3 - 4 } Viral loads $(I \mathrm{U} / \mathrm{mL})$ & Samples $(\mathrm{n})$ & Core, $\mathrm{n}(\%)$ & NS5B, $\mathrm{n}(\%)$ \\
\hline$<1000$ & 2 & $2(100)$ & $2(100)$ \\
$1000-10,000$ & 6 & $6(100)$ & $6(100)$ \\
$10,000-100,000$ & 33 & $32(97)$ & $31(93.9)$ \\
$100,000-1,000,000$ & 146 & $126(86.3)$ & $132(90.4)$ \\
$1,000,000-10,000,000$ & 176 & $174(98.9)$ & $161(91.5)$ \\
$>10,000,000$ & 6 & $6(100)$ & $6(100)$ \\
Total & 369 & $346(93.8)$ & $338(91.69)$ \\
\hline
\end{tabular}

$\mathrm{IU} / \mathrm{mL}$, international units per milliliter

(genotype 1), 5 (genotype 2) and 11 genotype (4), genotyping was based on core region only (Table 4 ). Interestingly, for two samples $(0.54 \%)$ discordant genotypes were obtained in both regions with the core region classified as genotype 4 while the NS5B was identified as genotype 1 indicating the presence of putative $\mathrm{HCV}$ recombinant viruses or multiple infections in these samples (Table 4). No phylogenetic relationship was found between the two sequences nor with previously described recombinant strains indicating the presence of two distinct viruses in both patients (Fig. 1). Due to the large number of sequences obtained in this study, only sequences of the two putative recombinant viruses were shown in the phylogenetic trees. However, all the sequences were submitted to the Genbank database (Accession numbers: MN208824-MN209169 for core sequences and MN208486-MN208823 for NS5B sequences).

Regarding the classification of $\mathrm{HCV}$ at the subtype level, subtype $4 \mathrm{f}$ was the more prevalent (22.55\%) followed by subtype 1e (11.68\%). Core and NS5B were not able to assign subtype to a relatively high proportion $(175 / 369 ; 47.4 \%)$ and were considered as not classified (nc) namely $2 \mathrm{nc}(23.64 \%), 1 \mathrm{nc}(13.32 \%)$ and $4 \mathrm{nc}(10.6 \%)$. Among the 346 sequences obtained in the core regions, subtype 1e was identified in 49 (14.2\%), 4f in 11 (3.2\%), $1 \mathrm{~b}$ in $2(0.58 \%), 1 \mathrm{~h}$ in $1(0.29 \%)$. For $281(80.2 \%)$ sequences, the subtype was not determined (nc) among which, $4 \mathrm{nc}$ in 129 (45.9\%), 2nc in 82 (23.7\%) and $1 \mathrm{nc}$ in $70(20.23 \%)$ samples. In the NS5B regions, more subtypes were identified and $80(23.67 \%)$ were classified as 4f, 22 as $11(6.51 \%), 13$ as $4 \mathrm{p}(3.85 \%), 10(2.96 \%)$ as $1 \mathrm{~h}$, $8(2.37 \%)$ as $4 \mathrm{t}, 2(0.59 \%)$ as $2 \mathrm{a}, 2$ as $1 \mathrm{~b}(0.59 \%)$ and finally subtypes $1 \mathrm{c}, 4 \mathrm{c}$ and $4 \mathrm{o}$ were identified in $1(0.30 \%)$ sample each. NS5B was not able to assign subtype for 198 samples (58.6\%) among which 1nc (84; 42.4\%), 2nc (83; $41.9 \%)$ and $4 \mathrm{nc}(31 ; 15.7 \%)$.

Among the 281 samples not classified by core region, 1 sample was classified as subtype $1 \mathrm{c}, 9$ as $1 \mathrm{~h}, 22$ as $1 \mathrm{l}$, 2 as $2 \mathrm{a}, 70$ as $4 \mathrm{f}, 1$ as $4 \mathrm{o}, 13$ as $4 \mathrm{p}$ and 7 as $4 \mathrm{t}$ by NS5B region (Table 5). Conversely, among the 198 samples not classified by NS5B region, 38 were identified as subtype $1 \mathrm{e}, 1 \mathrm{as} 1 \mathrm{~h}$ and 3 as $4 \mathrm{f}$ by the core region.

\section{Discussion}

Current DAA for HCV treatment are genotype specific and treatment duration can vary among genotypes. Therefore, HCV genotyping is essential for the therapeutic management of HCV infection and a variety of technologies have been developed for HCV genotypes determination. However sequences analysis of $\mathrm{HCV}$ sub-genomic regions (core, E1 and NS5 regions) is considered as gold standard and is widely used for HCV genotyping [10].

In this study, amplification rates were high and similar for core and NS5B regions (93.8 and 91.6\% respectively). Other studies have reported different results with a higher amplification rate for the core region compared to NS5B [15]. The core region is highly conserved and produces fewer false negative results in PCR reactions for HCV detection. Difficulty with NS5B region could sometimes be due to inadequate primer design, choice of highly polymorphic annealing sequences as well as low viral load [13].

Regarding amplification rate based on $\mathrm{HCV}$ viral load, we found no difference in both core and NS5B regions. In China, Cai et al. reported that amplification rate of both core and NS5B regions was correlated with viral load with a significant amplification rate of the core region when the viral load is $\geq 1 . \mathrm{E}+03 \mathrm{IU} / \mathrm{ml}$ [15]. This situation could be explained by different $\mathrm{HCV}$ genetic diversity in both countries where genotypes 1,3 and 6 are present in China, while genotypes 1, 2 and 4 are found in Cameroon.

$\mathrm{HCV}$ has a high genetic variability and our result is consistent with the genetic diversity of the virus in

Table 4 HCV genotypes classification in core and NS5B regions

\begin{tabular}{|c|c|c|c|c|c|}
\hline \multirow[b]{2}{*}{ NS5B } & \multicolumn{5}{|l|}{ Core } \\
\hline & Genotype 1 & Genotype 2 & Genotype 4 & No amplication & Total \\
\hline Genotype 1 & 107 & & 2 & 10 & 119 \\
\hline Genotype 2 & & 77 & & 8 & 85 \\
\hline Genotype 4 & & & 129 & 5 & 134 \\
\hline No amplication & 15 & 5 & 11 & & 31 \\
\hline Total & 122 & 82 & 142 & 23 & 369 \\
\hline
\end{tabular}

Putative recombinants/multiple infections are shown in bold 

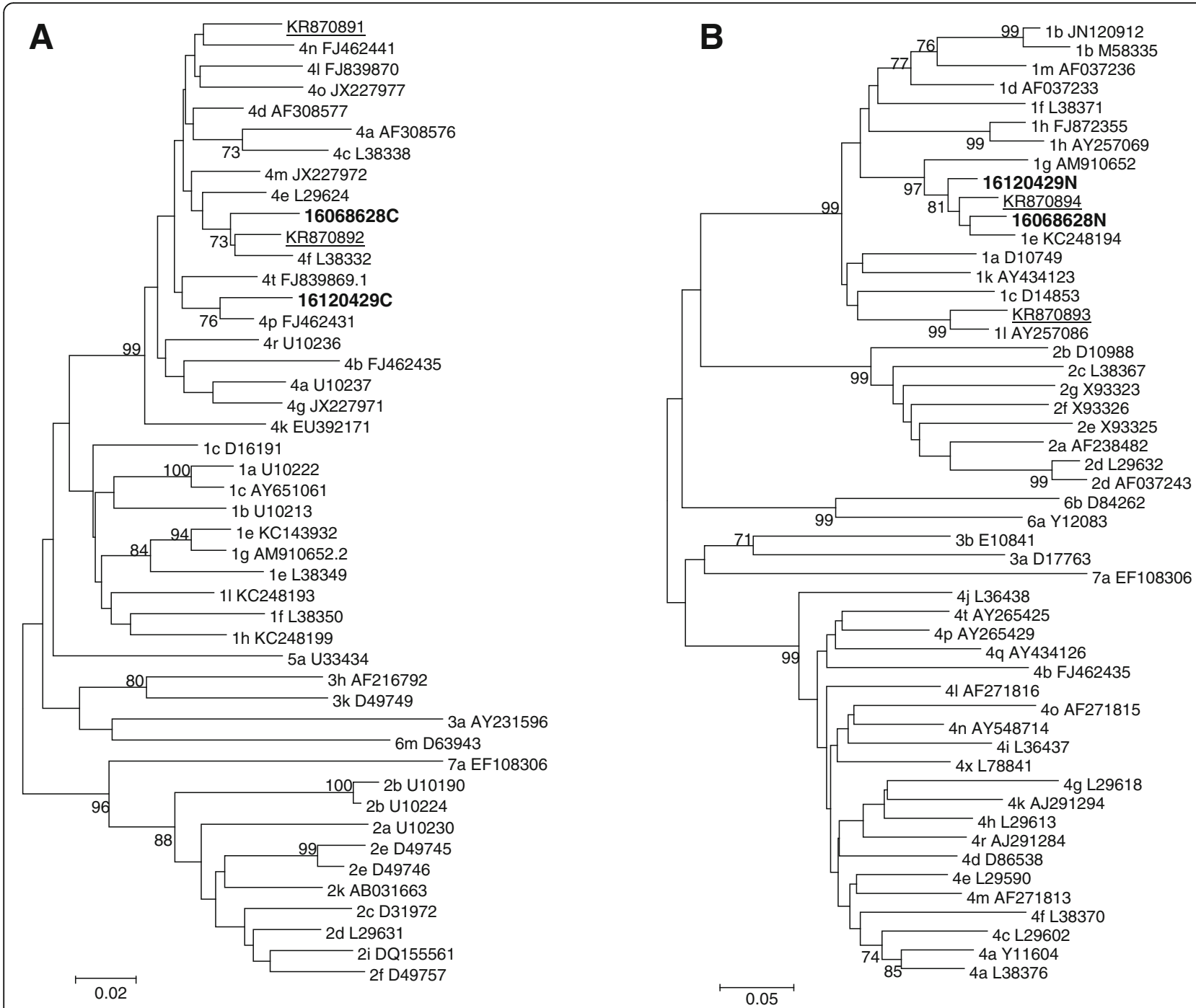

Fig. 1 Phylogenetic trees of the sequences derived from the core and NS5B regions of the putative recombinant viruses described in this work. The neighbour-joining tree is based on the core $(\mathbf{a})$ and NS5B (b) sequences. The sequences of putative recombinant viruses described here are shown in bold. Previously reported recombinants in Cameroon are underlined [18]. The reliability of the tree topologies was estimated by bootstrap analysis with 1000 pseudoreplicate data sets and for clarity, all bootstrap less than 70 have been omitted

Cameroon where genotypes 1,2 and 4 are found $[3,4]$. The predominance of genotype 4 followed by genotypes 1 and 2, is representative of the molecular epidemiology of $\mathrm{HCV}$ in Central Africa including Cameroon, where genotype 4 represents more than $80 \%$ followed by genotypes $1(12 \%)$ and $2(4 \%)$ [1]. The great genetic diversity of $\mathrm{HCV}$ virus in Cameroon provides a good environment for the co-circulation of multiples genotypes and subtypes which could lead to dual infections and the emergence recombinants. We found discordant genotypes with respect to core (genotype 4) and NS5B (genotype 1 ) in two samples (0.54\%) indicating the presence of putative $\mathrm{HCV}$ recombinants. However, data presented here is insufficient to establish the two sequences as recombinants because only Sanger sequencing on nested RT-
PCR fragments has been performed. Therefore, multiple infections (co-infections/superinfections) is also a possibility in the two samples. Recombination can occur with $\mathrm{HCV}$ as reported for other RNA viruses especially HIV [27]. However, characterization of near full length genomes will be more informative and also will help to confirm the mosaic pattern of these two viruses by Simplot analysis. Two other cases involving the same genotypes were previously reported in Cameroon [15]. This could probably be explained by the fact that genotypes 1 and 4 are prevalent in Cameroon compared to genotype $2[1,24]$. Recombination is a common phenomenon that occurs during replication of RNA viruses and this impact diagnosis, treatment and follow-up of infected patients [21]. Although, this phenomenon is rare in $\mathrm{HCV}$ virus, we should pay more attention on it because it is 
Table 5 Comparison of genotyping with core and NS5B sequences

\begin{tabular}{|c|c|c|c|c|c|c|c|c|c|c|c|}
\hline \multirow[b]{2}{*}{ NS5B } & \multirow[b]{2}{*}{$1 b$} & \multicolumn{10}{|c|}{ Core } \\
\hline & & $\overline{1 e}$ & $1 \mathrm{~h}$ & $1 \mathrm{nc}$ & $2 n c$ & $4 c$ & $4 f$ & $4 p$ & $4 \mathrm{nc}$ & No amplication & Total \\
\hline $1 b$ & 2 & & & & & & & & & & 2 \\
\hline $1 c$ & & & & 1 & & & & & & & 1 \\
\hline $1 \mathrm{~h}$ & & & & 9 & & & & & & 1 & 10 \\
\hline 11 & & & & 22 & & & & & & & 22 \\
\hline $1 \mathrm{nc}$ & & $\underline{38}$ & 1 & 34 & & & & 1 & 1 & 9 & 84 \\
\hline $2 a$ & & & & & 2 & & & & & & 2 \\
\hline $2 \mathrm{nc}$ & & & & & 75 & & & & & 8 & 83 \\
\hline $4 c$ & & & & & & 1 & & & & & 1 \\
\hline $4 f$ & & & & & & & 7 & & $\underline{70}$ & 3 & 80 \\
\hline $4 \mathrm{nc}$ & & & & & & & $\underline{3}$ & & 27 & 1 & 31 \\
\hline 40 & & & & & & & & & 1 & & 1 \\
\hline $4 p$ & & & & & & & & & $\underline{13}$ & & 13 \\
\hline $4 t$ & & & & & & & & & $\underline{7}$ & 1 & 8 \\
\hline No amplication & & 11 & & 4 & 5 & 1 & 1 & & 9 & & 31 \\
\hline Total & 2 & 49 & 1 & 70 & 82 & 2 & 11 & 1 & 128 & 23 & 369 \\
\hline
\end{tabular}

nc, not classified. Samples with discordant genotypes in core and NS5B regions (putative recombinants or multiple infections) are shown in bold and those were the subtype was not determined in one region but classified by the second region are underlined

relevant for clinical management of the infection regarding prognosis, natural history, and treatment recommendations as well as viral response [21, 22]. Therefore, at least two regions should be used for HCV genotyping to identify recombinant viruses or multiple infections and help to improve the therapeutic management of infected patients.

In this study, genotypes 1 and 4 were more heterogeneous with several subtypes: $1 \mathrm{~b}, 1 \mathrm{e}, 1 \mathrm{~h}, 4 \mathrm{c}$ and $4 \mathrm{f}$ for core region and $1 \mathrm{~b}, 1 \mathrm{c}, 1 \mathrm{~h}, 4 \mathrm{c}, 4 \mathrm{f}, 4 \mathrm{o}, 4 \mathrm{p}$ and $4 \mathrm{t}$ for NS5B (Table 5). Discrimination of $\mathrm{HCV}$ subtypes was most likely possible with NS5B compared to core region because more samples (80.2\%) were not classified at subtype level by core compared to $58.6 \%$ with NS5B. Similar findings were reported for 5 'non coding region, where identification of HCV genotypes was possible while classification at subtype level was not possible in this region [25]. This could be due to the fact that the NS5B gene has the highest phylogenetic signal compared to all the other $\mathrm{HCV}$ genes [3]. Therefore NS5B region is more suitable in epidemiological studies compared to core region [3]. Murphy et al. in their study also suggest NS5B genotyping as an effective tool for studying the molecular epidemiology of HCV [28]. No intersubtype recombinant was identified, however, for some few samples, the subtypes was determined in one region and not classified in the other region.

Our study has some limitations because no information on the treatment was available for all participants. The high proportion of not classified samples at subtype level for both core and NS5B regions could be due to the lack of reference sequences of some subtypes in the phylogenetic analysis. Analyzing these samples by another comparator such as LiPA would help to establish whether the method presented here is the best suited for genotyping/subtyping in Cameroonian patients. Regarding the two samples with discordant genotypes in the core and NS5B regions, multiple infections (co-infections/superinfections) is also a possibility because only Sanger sequencing on nested RT-PCR fragments has been performed. Data presented here is insufficient to establish the two sequences as recombinants.

\section{Conclusion}

In this study, we found high amplification rates of $\mathrm{HCV}$ in both core and NS5B regions, and a good concordance was obtained at genotype level using both regions except for two samples where putative 1-4 recombinant strains were detected. Since treatment option and duration are genotype specific $\mathrm{HCV}$ genotyping based on at least two genomic regions could help to identify putative recombinants/multiple infections and improve therapeutic management of $\mathrm{HCV}$ infection. However, even though recombination is rare in $\mathrm{HCV}$ infection, further studies are necessary to investigate clinical impacts of $\mathrm{HCV}$ recombinants.

\section{Abbreviations \\ 5'-UTR: 5' untranslated; DAA: Direct-acting antivirals; HCV: Hepatitis C virus; IU/mL: International units per milliliter; LiPA: Line probe assay; Nc: not classified; NS5B: Non-structural protein 5B; RFLP: Restriction fragment length polymorphism}

\section{Acknowledgements}

We are grateful to all the patients for the data provided. All the data presented here were anonymously analyzed and reported.

\section{Authors' contributions}

RN designed the study, RB, SFL and LN performed the experiments; PATN, SK performed statistical analyses; PATN, MNN and MAA drafted the manuscript; 
all the authors were substantially involved in editing and validation of the manuscript. All authors read and approved the final manuscript.

\section{Funding}

This research did not receive any specific grant from funding agencies in the public, commercial, or not-for-profit sectors.

\section{Availability of data and materials}

The nucleotide sequences of HCV described in this study were submitted to the Genbank database and accession are MN208824-MN209169 for core sequences and MN208486-MN208823 for NS5B sequences.

\section{Ethics approval and consent to participate}

Not applicable.

\section{Consent for publication}

Not applicable.

\section{Competing interests}

The authors declare that they have no competing interests.

Received: 21 May 2019 Accepted: 6 August 2019

Published online: 09 August 2019

\section{References}

1. Petruzziello A, Marigliano S, Loquercio G, Cozzolino A, Cacciapuoti C. Global epidemiology of hepatitis $C$ virus infection: an up-date of the distribution and circulation of hepatitis C virus genotypes. World J Gastroenterol. 2016;22:7824-40.

2. Smith DB, Bukh J, Kuiken C, Muerhoff AS, Rice CM, Stapleton JT, Simmonds P. Expanded classification of hepatitis C virus into 7 genotypes and 67 subtypes: updated criteria and genotype assignment web resource. Hepatology. 2014;59:318-27.

3. Pasquier C, Njouom R, Ayouba A, Dubois M, Sartre MT, Vessiere A, Timba I, Thonnon J, Izopet J, Nerrienet E. Distribution and heterogeneity of hepatitis C genotypes in hepatitis patients in Cameroon. J Med Virol. 2005;77:390-8.

4. Njouom R, Pasquier C, Ayouba A, Sandres-Saune K, Mfoupouendoun J, Mony Lobe M, Tene G, Thonnon J, Izopet J, Nerrienet E. Hepatitis C virus infection among pregnant women in Yaounde, Cameroon: prevalence, viremia, and genotypes. J Med Virol. 2003;69:384-90.

5. D'Ambrosio R, Degasperi E, Colombo M, Aghemo A. Direct-acting antivirals: the endgame for hepatitis C? Curr Opin Virol. 2017;24:31-7.

6. Tong L, Yu W, Chen L, Selyutin O, Dwyer MP, Nair AG, Mazzola R, Kim JH, Sha D, Yin J, et al. Discovery of Ruzasvir (MK-8408): a potent, pan-genotype HCV NS5A inhibitor with optimized activity against common resistanceassociated polymorphisms. J Med Chem. 2017;60:290-306.

7. Yu W, Coburn CA, Yang DY, Meinke PT, Wong M, Rosenblum SB, Chen KX, Njoroge GF, Chen L, Dwyer MP, et al. Discovery of fused tricyclic core containing HCV NS5A inhibitors with pan-genotype activity. Bioorg Med Chem Lett. 2016;26:3158-62.

8. WHO: Guidelines for the care and treatment of persons diagnosed with chronic hepatitis c virus infection. 2018.

9. Maughan A, Sadigh K, Angulo-Diaz V, Mandimika C, Villanueva M, Lim JK, Ogbuagu O. Contemporary HCV pangenotypic DAA treatment protocols are exclusionary to real world HIV-HCV co-infected patients. BMC Infect Dis. 2019;19:378.

10. Buoro S, Pizzighella S, Boschetto R, Pellizzari L, Cusan M, Bonaguro R, Mengoli C, Caudai C, Padula M, Egisto Valensin P, Palu G. Typing of hepatitis $C$ virus by a new method based on restriction fragment length polymorphism. Intervirology. 1999:42:1-8.

11. Stuyver $L$, Rossau R, Wyseur A, Duhamel M, Vanderborght B, Van Heuverswyn $\mathrm{H}$, Maertens $\mathrm{G}$ : Typing of hepatitis $\mathrm{C}$ virus isolates and characterization of new subtypes using a line probe assay. J Gen Virol 1993; 74 ( Pt 6):1093-1102.

12. Avo AP, Agua-Doce I, Andrade A, Padua E. Hepatitis C virus subtyping based on sequencing of the C/E1 and NS5B genomic regions in comparison to a commercially available line probe assay. J Med Virol. 2013;85:815-22.

13. Nakatani SM, Santos CA, Riediger IN, Krieger MA, Duarte CA, do Carmo Debur M, Carrilho FJ, Ono SK. Comparative performance evaluation of hepatitis $C$ virus genotyping based on the $5^{\prime}$ untranslated region versus partial sequencing of the NS5B region of brazilian patients with chronic hepatitis C. Virol J. 2011:8:459.
14. Simmonds P, Smith DB, McOmish F, Yap PL, Kolberg J, Urdea MS, Holmes EC Identification of genotypes of hepatitis $C$ virus by sequence comparisons in the core, E1 and NS-5 regions. J Gen Virol 1994;75 ( Pt 5):1053-1061.

15. Cai Q, Zhao Z, Liu Y, Shao X, Gao Z. Comparison of three different HCV genotyping methods: core, NS5B sequence analysis and line probe assay. Int J Mol Med. 2013;31:347-52.

16. Kassela K, Karakasiliotis I, Kokkiou E, Souvalidou F, Mimidis P, Veletza S, Panopoulou M, Koskinas J, Mimidis K, Mavromara P. Intergenotypic 2K/1b hepatitis $C$ virus recombinants in the East Macedonia and Thrace region of Greece. Ann Gastroenterol. 2019;32:88-92.

17. Zakalashvili M, Zarkua J, Weizenegger M, Bartel J, Raabe M, Zangurashvili L, Kankia N, Jashiashvili N, Lomidze M, Telia T, et al. Identification of hepatitis C virus 2k/1b intergenotypic recombinants in Georgia. Liver Int. 2018;38:451-7.

18. Iles JC, Njouom R, Foupouapouognigni Y, Bonsall D, Bowden R, Trebes A, Piazza P, Barnes E, Pepin J, Klenerman P, Pybus OG. Characterization of hepatitis $C$ virus recombination in Cameroon by use of nonspecific nextgeneration sequencing. J Clin Microbiol. 2015;53:3155-64.

19. Kalinina O, Norder H, Mukomolov S, Magnius LO. A natural intergenotypic recombinant of hepatitis C virus identified in St. Petersburg. J Virol. 2002;76:4034-43.

20. Legrand-Abravanel F, Claudinon J, Nicot F, Dubois M, Chapuy-Regaud S, Sandres-Saune K, Pasquier C, Izopet J. New natural intergenotypic (2/5) recombinant of hepatitis C virus. J Virol. 2007;81:4357-62

21. Morel V, Fournier C, Francois C, Brochot E, Helle F, Duverlie G, Castelain S. Genetic recombination of the hepatitis $C$ virus: clinical implications. J Viral Hepat. 2011;18:77-83.

22. Gonzalez-Candelas F, Lopez-Labrador FX, Bracho MA. Recombination in hepatitis C virus. Viruses. 2011;3:2006-24.

23. Lole KS, Jha JA, Shrotri SP, Tandon BN, Prasad VG, Arankalle VA. Comparison of hepatitis $C$ virus genotyping by $5^{\prime}$ noncoding region- and core-based reverse transcriptase PCR assay with sequencing and use of the assay for determining subtype distribution in India. J Clin Microbiol. 2003;41:5240-4.

24. Njouom R, Caron M, Besson G, Ndong-Atome GR, Makuwa M, Pouillot R, Nkoghe D, Leroy E, Kazanji M. Phylogeography, risk factors and genetic history of hepatitis C virus in Gabon, Central Africa. PLoS One. 2012;7:e42002.

25. Laperche S, Lunel F, Izopet J, Alain S, Deny P, Duverlie G, Gaudy C, Pawlotsky JM, Plantier JC, Pozzetto B, et al. Comparison of hepatitis C virus NS5b and 5' noncoding gene sequencing methods in a multicenter study. J Clin Microbiol. 2005;43:733-9.

26. Tamura K, Stecher G, Peterson D, Filipski A, Kumar S. MEGA6: molecular evolutionary genetics analysis version 6.0. Mol Biol Evol. 2013;30:2725-9.

27. Ngoupo PA, Sadeuh-Mba SA, De Oliveira F, Ngono V, Ngono L, Tchendjou P, Penlap V, Mourez T, Njouom R, Kfutwah A, Plantier JC. First evidence of transmission of an HIV-1 M/O intergroup recombinant virus. Aids. 2016;30:1-8.

28. Murphy DG, Willems B, Deschenes M, Hilzenrat N, Mousseau R, Sabbah S. Use of sequence analysis of the NS5B region for routine genotyping of hepatitis $C$ virus with reference to C/E1 and 5' untranslated region sequences. J Clin Microbiol. 2007;45:1102-12.

\section{Publisher's Note}

Springer Nature remains neutral with regard to jurisdictional claims in published maps and institutional affiliations.

Ready to submit your research? Choose BMC and benefit from:

- fast, convenient online submission

- thorough peer review by experienced researchers in your field

- rapid publication on acceptance

- support for research data, including large and complex data types

- gold Open Access which fosters wider collaboration and increased citations

- maximum visibility for your research: over $100 \mathrm{M}$ website views per year

At BMC, research is always in progress.

Learn more biomedcentral.com/submissions 